\title{
ANALISIS PENGARUH PENERAPAN SISTEM INFORMASI KEUANGAN, SISTEM PENGAWASAN MELEKAT DAN PRINSIP TRANSPARANSI TERHADAP AKUNTABILITAS PENGELOLAAN ANGGARAN PENDAPATAN DAN BELANJA DAERAH (APBD) (STUDI EMPIRIS PADA DPRD KABUPATEN REMBANG)
}

\author{
Rosa Nikmatul Fajri, Djumali, Sri Hartono \\ Universitas Islam Batik Surakarta
}

\begin{abstract}
This study discusses the Analysis of the Effect of the Implementation of the Financial Information System, the Adherent Supervision System and the Transparency Principle on the Management of Regional Budget and Expenditure (APBD) which will be carried out in the Rembang Regional Representative Council (DPRD) Secretariat. In this study aims to determine the direction of budget realization at the Secretariat, knowing the effectiveness and efficiency of the inherent supervision system and proving that the principle of transparency is optimal in its implementation. Sources of data and data collection methods The main research needed is to use primary data, namely data sources obtained from respondents through surveys, questionnaires and purposive sampling. Data analysis using Smart Partial Least Square (SmartPLS). In this study concluded that 1) $\mathrm{t}$ statistics $>$ from $\mathrm{t}$ table is significant at 0.05 ( $\mathrm{t}$ statistics $>\mathrm{t}$ table 1.96). This means that Hypothesis 1 (H1) which states that "The application of regional financial information systems has a positive effect on the accountability of APBD management", 2) the effect of the inherent supervision system on the accountability of APBD management has a statistic of 3,150699 . So $t$ statistic $>$ from $t$ table is significant at 0.05 ( $t$ statistic $>t$ table 1.96 ), this means that Hypothesis 2 (H2) states that "The inherent supervision system has a positive effect on the accountability of APBD management.", And 3) influence the principle of transparency towards accountability of APBD management has $t$ statistics of 7,270543. So $t$ statistic $>$ from $t$ table is significant at 0.05 ( $\mathrm{t}$ statistics $>\mathrm{t}$ table 1.96), this means that Hypothesis 3 (H3) states that "The application of the principle of transparency has a positive effect on the accountability of APBD management".
\end{abstract}
Keywords : Regional Financial Information System, Adhering Supervision System, Transparency Principle, Accountability for Management of Regional Budget (APBD)

Correspondence to : rosanikmatulfajri@mail.ugm.ac.id 


\section{ABSTRAK}

Penelitian ini membahas tentang Analisis Pengaruh Penerapan Sistem Informasi Keuangan, Sistem Pengawasan Melekat dan Prinsip Transparansi terhadap Akuntabilitas Pengelolaan Anggaran Pendapatana dan Belanja Daerah (APBD) yang akan dilaksanakan pada bagian Sekretariat Dewan Perwakilan Rakyat Daerah (DPRD) Rembang. Dalam penelitian ini bertujuan untuk mengetahui arah realisasi anggaran pada Sekretariat, mengetahui keefektifan dan keefesiensian dari system pengawasan melekat dan membuktikan bahwa prinsip transparansi sudah optimal dalam penyelenggaraannya. Sumber data dan metode pengumpulan data penelitian utama yang diperlukan adalah menggunakan data primer yaitu sumber data yang diperoleh dari responden melalui survey, kuesioner dan purposive sampling. Analisis data menggunakan Smart Partial Least Square (SmartPLS). Dalam penelitian ini berkesimpulan bahwa 1) $t$ statistik $>$ dari t tabel signifikan pada 0,05 (t statistik $>\mathrm{t}$ tabel 1,96). Ini berarti bahwa Hipotesis $1\left(\mathrm{H}_{1}\right)$ yang menyatakan bahwa "Penerapan sistem informasi keuangan daerah berpengaruh positif terhadap akuntabilitas pengelolaan APBD", 2) pengaruh sistem pengawasan melekat terhadap akuntabilitas pengelolaan APBD mempunyai $t$ statistik sebesar 3,150699. Jadi t statistik $>$ dari $t$ tabel signifikan pada $0,05(\mathrm{t}$ statistik $>\mathrm{t}$ tabel 1,96), ini berarti bahwa Hipotesis2 $\left(\mathrm{H}_{2}\right)$ yang menyatakan bahwa "Sistem pengawasan melekat berpengaruh positif terhadap akuntabilitas pengelolaan APBD." , dan 3) pengaruh prinsip transparansi terhadap akuntabilitas pengelolaan APBD mempunyai $t$ statistik sebesar 7,270543. Jadi t statistik $>$ dari $t$ tabel signifikan pada 0,05 ( $\mathrm{t}$ statistik $>\mathrm{t}$ tabel 1,96$)$, ini berarti bahwa Hipotesis3 $\left(\mathrm{H}_{3}\right)$ yang menyatakan bahwa "Penerapan prinsip transparansi berpengaruh positif terhadap akuntabilitas pengelolaan APBD”.

Kata kunci $\quad$ : Sistem Informasi Keuangan Daerah, Sistem Pengawasan Melekat, Prinsip Transparansi, Akuntabilitas Pengelolaan Anggaran Pendapatan dan Belanja Daerah (APBD)

Korespondensi $\quad$ : rosanikmatulfajri@mail.ugm.ac.id

\section{PENDAHULUAN / INTRODUCTION}

Menurut UNDP (United Nation Development Program), akuntabilitas merupakan salah satu prinsip dari good governance, yang menyebutkan bahwa akuntabilitas adalah kewajiban untuk mempertanggungjawabkan kinerjanya. Sedangkan menurut Turner dan Hulme (1997), bahwa akuntabilitas merupakan konsep yang komplek yang lebih sulit mewujudkannya daripada memberantas korupsi. Akuntabilitas adalah keharusan lembaga-lembaga sektor publik untuk lebih menekan pada pertanggungjawaban horizontal (masyarakat) bukan hanya pertanggungjawaban vertikal (otoritas yang lebih tinggi). Jadi dapat disimpulkan bahwa penggunaan prinsip akuntabilitas sangat penting dan perlu diperhatikan untuk dilaksanakan karena prinsip ini dapat membantu badan atau instansi pemerintahan dalam pertanggungjawaban kepada publik, baik segi hasil maupun segi finansial melalui pemeriksaan keuangan yang digunakan penilaian atas kinerja yang diperoleh. Akuntabilitas hasil tersebut sebenarnya tidak melihat dari segi input maupun output melainkan melihat dari segi outcome-nya. Sedangkan akuntabilitas finansial melihat penggunaan dana secara efektif dan efesien serta tidaknya kebocoran dana tersebut. Dan juga bahwa prinsip akuntabilitas ini dianggap sangat menguntungkan apabila prinsip ini diterapkan untuk proses pengelolaan keuangan, terutama 
keuangan yang bersumber dari Anggaran Pendapatan dan Belanja Daerah (APBD) pada instansi-instansi pemerintahan daerah.

Dalam kaitan dengan pengelolaan keuangan yang bersumber dari APBD pada instansi-instansi pemerintahan daerah, UU Nomor 32 Tahun 2004 dalam Pasal 156 menjelaskan bahwa kepala daerah adalah pemegang kekuasaan pengelolaan keuangan daerah. Dalam melaksanakan kekuasaan tersebut, kepala daerah melimpahkan sebagian atau seluruh kekuasaannya yang berupa perencanaan, pelaksanaan, penatausahaan, pelaporan dan pertanggungjawaban, serta pengawasan keuangan daerah kepada para pejabat perangkat daerah. Dengan demikian, pengelolaan dan pertanggungjawaban keuangan yang bersumber dari APBD dilaksanakan oleh para pejabat daerah dalam hal ini para kepala instansi pemeintah daerah, yang selnjutnya dilaporkan kembali hasil pelaksanaan tersebut kepada pelimpah kekuasaan keuangan dalam hal ini adalah kepala daerah.

Dengan keadaan yang demikian itu maka pemerintah mengeluarkan UU Nomor 33 Tahun 2004 dalam Peraturan Pemerintah Nomor 56 Tahun 2005 tentang Sistem Informasi Keuangan Daerah. Sistem informasi keuangan daerah menurut Departemen Keuangan RI (2006) adalah suatu sistem yang mendokumentasikan, mengadministrasikan, mengelola data pengelolaan keuangan daerah, data terkait lainnya menjadi informasi yang disajikan kepada masyarakat sebagai bahan pengambilan keputusan dalam rangka perencanaan, pelaksanaan, dan pelaporan pertanggungjawaban pemerintah.

Untuk mewujudkan pertanggungjawaban pemerintah terhadap publik salah satu cara dilakukan dengan menggunakan prinsip transparansi (keterbukaan). Menurut Forum dosen akuntansi sektor publik (2006) bahwa transparansi berarti keterbukaan (opennsess) pemerintah dalam memberikan informasi yang terkait dengan aktivitas pengelolaan seumber daya publik kepada pihak - pihak yang membutuhkan informasi. Untuk mempermudah proses pengelolaan APBD, pemerintah daerah berusaha menggalakkan penerapan sistem informasi yang dapat membantunya untuk mempertanggungjawabkan keuangan daerah dalam jangka periode tertentu kepada publik. Hal ini juga diungkapkan oleh Mardiasmo (2002) bahwa transparansi pengelolaan keuangan daerah pada akhirnya akan menciptakan horizontal accountability antara pemerintah daerah dengan masyarakatnya sehingga tercipta pemerintahan daerah yang bersih, efektif, efisien, akuntabel, dan responsif terhadap aspirasi dan kepentingan masyarakat.

Demi mendukung pelaksanaan akuntabilitas pengelolaan APBD maka sebuah sistem informasi keuangan daerah yang menganut prinsip transparansi tersebut harus disertai dengan sistem pengendalian, karena fungsi sistem pengendalian merupakan alat untuk menjaga asas transparansi yaitu asas yang membuka diri terhadap hak masyarakat untuk memperoleh informasi yang benar, jujur, dan tidak diskriminatif tentang penyelenggaraan negara dengan tetap memperhatikan perlindungan atas hak asasi pribadi, golongan dan rahasia negara.

Dalam pemerintahan, digunakan istilah sistem pengawasan untuk mengacu penggunaan istilah sistem pengendalian karena secara formal hanya bersifat memberikan saran dan secara murni tidak memiliki hak untuk melakukan koreksi. Menurut Anthony dan Govindrajan (2011) bahwa sistem merupakan suatu cara tertentu dan biasanya bersifat pengulangan untuk melakukan sekelompok aktivitas. Namun, berbeda dengan pendapat Krismiaji (2005) bahwa sistem ini dapat didefinisikan serangkaian komponen yang dikoordinasikan untuk mencapai serangkaian tujuan. 
Menurut Lembaga Administrasi Negara Republik Indonesia (LAN RI) (2003) disebutkan bahwa yang dimaksud dengan pengawasan adalah sustu kegiatan untuk memperoleh kepastian dari pelaksanaan pekerjaan atau kegiatan yang telah dilakukan sesuai dengan rencana semula. Sedangkan menurut Baswir (1995 dalam Ulum MD 2009), pengawasan adalah suatu proses kegiatan yang dilakukan secara terus menerus atau berkesinambungan untuk mengamati, memahami dan menilai setiap pelaksanaan kegiatan tertentu sehingga dapat dicegah atau diperbaiki kesalahan atau penyimpangan yang terjadi.

Menurut Lembaga Administrasi Negara Republik Indonesia (LAN RI) (2003), bahwa bentuk-bentuk pengawasan adalah sebagai berikut:

1. Pengawasan Fungsional

Pengawasan fungsional adalah setiap upaya pengawasan yang dilaksanakan oleh aparat yang ditunjuk khusus untuk melakukan audit secara independen terhadap obyek yang diawasinya.

2. Pengawasan Melekat

Menurut Instruksi Presiden Nomor 1 tahun 1989 tentang Pedoman Pengawasan Melekat disebutkan bahwa pengawasan melekat merupakan serangkaian kegiatan yang bersifat sebagai pengendalian yang terus-menerus, dilakukan atasan langsung terhadap bawahannya secara preventif dan represif agar pelaksanaan tugas bawahan tersebut berjalan secara efektif dan efisien sesuai dengan rencana kegiatan dan peraturan perundangan yang berlaku.

Sistem pengawasan melekat di instansi pemerintah pada hakikatnya hanya untuk menghindari adanya tindak penyelewengan atau penyimpangan atas tujuan yang akan dicapai. Melalui sistem pengawasan melekat diharapkan dapat membantu melaksanakan kebijakan yang telah ditetapkan untuk mencapai tujuan yang telah direncanakan secara efektif dan efisien.

Penelitian yang diangkat ini mengacu pada penelitian yang telah dilakukan oleh Widyaningsih, Triantoro dan Wiyantoro (2011) yang meneliti mengenai hubungan efektifitas sistem akuntansi keuangan dan pengendalian intern dengan kualitas akuntabilitas keuangan: kualitas informasi laporan keuangan sebagai variable intervening. Dengan merepelikasi penelitian yang telah dilakukan oleh Widyaningsih, Triantoro dan Wiyantoro (2011), penulis hanya ingin mengetahui apakah ada perbedaan dari hasil penelitian terdahulu dengan penelitian yang akan dilakukan saat ini di Dewan Perwakilan Rakyat Daerah (DPRD) Kabupaten Rembang. Penelitian ini menggunakan sampel yang berbeda dan terdapat perubahan variabel dari penelitian sebelumnya. Variabel independen dalam penelitian ini adalah sistem informasi keuangan daerah, pengawasan melekat dan prinsip transparansi sedangkan variabel dependen yang digunakan adalah akuntabilitas pengelolaan anggaran pendapatan dan belanja daerah (APBD).

Adapun pemilihan lokasi penelitian di DPRD Kabupaten Rembang diambil dengan alasan-alasan sebagai berikut: 1) DPRD merupakan unsur pemerintahan daerah yang pembiayaan pelaksanaan tugasnya bersumber dari APBD yang sudah barang tentu harus dipertanggungjawabkan secara akuntabel; 2) Untuk saat ini, DPR dan DPRD menjadi sorotan publik baik yang menyangkut kinerjanya maupun anggarannya, sehingga menarik untuk diteliti; 3) Penulis berasal dari Kabupaten Rembang, sehingga akan lebih memudahkan pengambilan data-data yang diperlukan.

Berdasarkan uraian di atas, penulis tertarik untuk melakukan penelitian yang berjudul "Analisis Pengaruh Penerapan Sistem Informasi Keuangan Daerah, Pengawasan 
Melekat dan Prinsip Transparansi terhadap Akuntabilitas Pengelolaan Anggaran Pendapatan dan Belanja Daerah (APBD)".

Tujuan dari penelitian ini dapat adalah sebagai berikut:

1. Untuk mengetahui pengaruh penerapan sistem informasi keuangan daerah secara signifikan terhadap akuntabilitas pengelolaan anggaran pendapatan dan belanja daerah (APBD)

2. Untuk mengetahui pengaruh sistem pengawasan melekat secara signifikan terhadap akuntabilitas pengelolaan anggaran pendapatan dan belanja daerah (APBD)

3. Untuk mengetahui pengaruh prinsip transparansi secara signifikan terhadap akuntabilitas pengelolaan anggaran pendapatan dan belanja daerah (APBD)

\section{Kerangka Teoritik}

Aribowo (2007 dalam Widyaningsih, Triantoro dan Wiyantoro 2011) mengemukakan bahwa akuntabilitas menunjukkan kewajiban untuk melaporkan secara akurat dan tepat waktu tentang informasi yang terkait dengan pertanggungjawaban pemerintahan. Selain itu, menurut Sulistoni (2003 dalam Sopanah dan Wahyudi 2010), pemerintahan yang accountable memiliki ciri-ciri sebagai berikut: (1) mampu menyajikan informasi penyelenggaraan pemerintah secara terbuka, cepat, dan tepat kepada masyarakat; (2) mampu memberikan pelayanan yang memuaskan bagi publik; (3) mampu memberikan ruang bagi masyarakat untuk terlibat dalam proses pembangunan dan pemerintahan; (4) mampu menjelaskan dan mempertanggungjawabkan setiap kebijakan publik secara proporsional; dan (5) adanya sarana bagi publik untuk menilai kinerja pemerintah. Melalui pertanggungjawaban publik, masyarakat dapat menilai derajat pencapaian pelaksanaan program dan kegiatan pemerintah. Dengan demikian dapat disimpulkan bahwa suatu kegitan dikatakan memiliki akuntabilitas apabila kegiatan tersebut dapat dilaporkan hasilnya secara akurat, tepat waktu dan terbuka bagi masyarakat luas dan pihak pihak yang berkepentingn. Dengan kata lain, accountable berarti memiliki kemampuan melaporkan hasil secara akurat dan tepat waktu dan terbuka.

\section{Sistem Informasi Keuangan Daerah Berpengaruh terhadap Akuntabilitas Pengelolaan APBD}

Menurut Mardiyanto (2009), Sistem Informasi Keuangan / Finansial merupakan sistem informasi yang memberikan informasi kepada seluruh manager keuangan yang berkaitan dengan aktivitas keuangan perusahaan. Aktifitas-aktifitas keluaran dari sistem informasi keuangan yaitu peramalan tren perekonomian masa depan, mengelola aliran dana yang melalui perusahaan dan mengendalikan keuangan perusahaan.

Menurut Pasal 3 UU Nomor 33 Tahun 2004, informasi keuangan yang disampaikan harus memenuhi prinsip-prinsip: 1) akurat adalah suatu tindakan yang mencerminkan ketelitian, kecermatan dan ketepatan; 2) relevan adalah suatu keadaan yang sesuai dengan kondisi obyektif sekarang dan masa datang; dan 3) dapat dipertanggungjawabkan adalah suatu kondisi atau fakta yang dapat diperbandingkan secara angka nominal dan matematis.

Menurut Kharisma (2012), fungsi utama dari sistem informasi keuangan daerah adalah: 1) membantu pemerintah daerah dalam pengelolaan keuangan daerah yang mencakup perencanaan, pengelolaan dan pertanggungjawaban; 2) menyusun laporan keuangan yang lebih efektif dan akurat; 3) menyimpan data keuangan untuk keperluan manajemen lainnya; dan 4) menyajikan informasi yang akurat, efektif dan efisien bagi pengguna laporan. 
Dikaitkan dengan uraian mengenai akuntabilitas, maka dapat disimpulkan bahwa penerapan sistem informasi keuangan yang akurat akan mempengaruhi informasi/pengelolaan keuangan yang akurat juga, sehingga hasilnya dapat dipertangungjawabkan. Dengan adanya hasil yang akurat dan dapat dipertanggungjawabkan maka penerapan sistem informasi keuangan dapat berperan positif dalam mewujudkan akuntabilitas pengelolaan APBD.

\section{Pengaruh Sistem Pengawasan Melekat terhadap Akuntabilitas Pengelolaan APBD}

Nawawi (1989 dalam Deutary 2012) mengemukakan bahwa pengawasan melekat adalah proses pemantauan, pemeriksaan dan evaluasi atasan langsung terhadap pekerjaan dan hasil kerja bawahan agar dapat mencegah terjadinya penyalahgunaan wewenang dan penyimpangan dari ketentuan-ketentuan, peraturan-peraturan, dan kebijakan-kebijakan yang telah ditetapkan. Fungsi pengawasan melekat merupakan proses atau usaha-usaha untuk mengawasi serta mengendalikan pegawai secara langsung yang dilakukan oleh setiap unsur pimpinan dalam suatu organisasi, sehingga dirasakan lebih efektif untuk mampu menjangkau semua lini dalam unit kerja yang ada. Sedangkan menurut Nawawi (1998), tujuan dari pengawasan melakat untuk mewujudkan daya guna, hasil guna, dan tepat guna dalam upaya mencapai sasaran-sasaran di dalam program-program pemerintahan.

Berdasarkan pendapat-pendapat di atas dapat disimpulkan bahwa sasaran akhir dari pengawasan melekat adalah menjaga agar tujuan organisasi dapat dicapai dengan maksimal dan terhindar dari penyimpanganpenyimpangan yang terjadi. Dengan demikian kegiatan yang dikawal dengan pengawasan melekat yang dilakukan terus menerus oleh atasan secara langsung dapat menghasilkan keluaran yang akurat, karena terhindar dari penyimpangan penyimpangan, dan dapat dipertanggungjawabkan karena lebih efektif dan efisien terhadap pencapaian tujuan kegiatan.

Apabila pelaksanaan pengawasan melakat tersebut dapat membawa hasil yang lebih akurat dan dapat dipertanggungjawabkan, maka dapat disimpulkan bahwa pengawasan melekat atas pengelolaan keuangan berkontribusi positif terhadap terwujudnya akuntabilitas pengelolaan APBD. Dengan kata lain pengawasan melekat berpengaruh positif terhadap akuntabilitas pengelolaan APBD.

\section{Prinsip Transparansi berpengaruh terhadap Akuntabilitas Pengelolaan APBD}

Menurut Badan Pertimbangan Pendidikan Nasional (BPPN) dan Departemen Dalam Negeri (2002) mengemukakan bahwa transparansi adalah prinsip yang menjamin akses atau kebebasan bagi setiap orang untuk memperoleh informasi tentang penyelenggaraan pemerintah, yakni informasi tentang kebijakan, proses pembuatan dan pelaksanaannya, serta hasil-hasil yang dicapai. Sedangkan transparansi menurut Mardiasmo (2002) yaitu keterbukaan pemerintah dalam membuat kebijakan-kebijakan keuangan daerah sehingga dapat diketahui dan diawasi oleh DPRD dan masyarakat.

Menurut Krina (2003) indikatorindikator dari transparansi adalah sebagai berikut: 1) penyediaan informasi yang jelas tentang prosedur-prosedur, biaya-biaya dan tanggung jawab; 2) kemudahan akses informasi; 3) menyusun suatu mekanisme pengaduan jika ada peraturan yang dilanggar atau permintaan untuk membayar uang suap; dan 4) meningkatkan arus informasi melalui kerjasama dengan media massa dan lembaga non pemerintah.

Menurut Silviana (2012) dua elemen penting dalam transparasi pemerintahan: 1) adanya akses, kemungkinan seseorang untuk mendapatkan informasi terhadap aktivitas 
pejabat pemerintahan; 2) adanya akurasi informasi, artinya informasi yang disampaikan sesuai dengan kenyataan atau valid. Dan tujuan transparasi dalam pemerintahan: 1) mengurangi apatisme masyarakat terhadap pribadi pejabat pemerintah; 2) memudahkan pelaksanaan audit atau pengawasan terhadap penyelenggaraan pemerintah; 3) meminimalisasikan konflik kepentingan antara rakyat dengan pejabat pemerintah dan antar pejabat.

Berdasarkan uraian diatas, maka skema berpikir tentang pengaruh sistem informasi keuangan daerah, penerapan sistem pengawasan melekat dan penerapan prinsip transparansi terhadap terciptanya akuntabiitas pengelolaan APBD dapat digambarkan sebagai berikut:

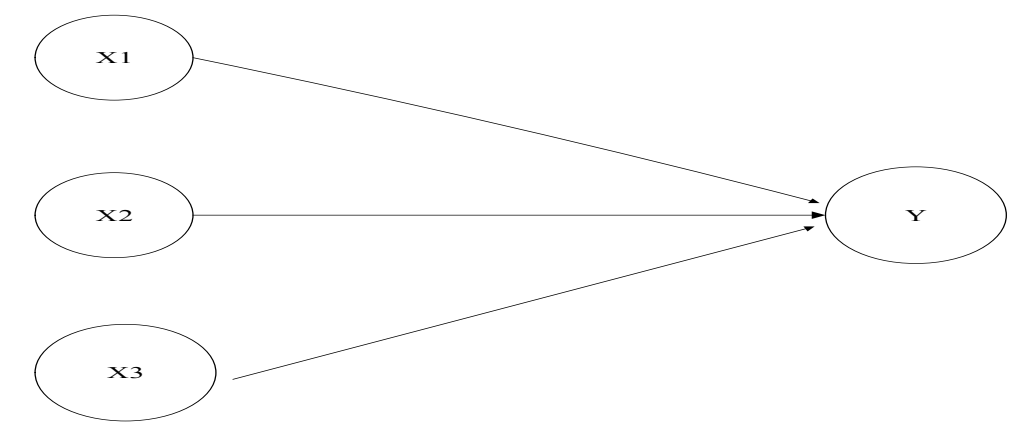

Keterangan:

$\mathrm{X} 1$ adalah penerapan sistem informasi keuangan;

$\mathrm{X} 2$ adalah sistem pengawasan melekat;

$\mathrm{X} 3$ adalah prinsip transparansi atas keuangan;

$\mathrm{Y}$ adalah akuntabilitas pengelolaan APBD.

\section{Pengujian Hipotesis}

\section{Pengaruh Sistem Informasi Keuangan Daerah terhadap Akuntabilitas Pengelolaan APBD}

Pemerintah Daerah selaku pengelola dana publik harus mampu menyediakan informasi keuangan yang diperlukan secara akurat, relevan, tepat waktu, dan dapat dipercaya. Maka Pemerintah Daerah dituntut memiliki sistem informasi yang andal. Jika sistem informasi akuntansi yang dimiliki masih lemah, kualitas informasi yang dihasilkan dari sistem tersebut juga kurang andal. Oleh karena itu dalam rangka memantapkan otonomi daerah dan desentralisasi, Pemerintah Daerah hendaknya sudah mulai memikirkan investasi untuk pengembangan sistem informasi akuntansi, Wahyundaru (2001 dalam penelitian
Atarwaman 2008). Sehingga hipotesis utamanya dirumuskan sebagai berikut:

H1:Penerapan sistem informasi keuangan daerah berpengaruh positif terhadap akuntabilitas pengelolaan APBD.

Pengaruh Sistem Pengawasan Melekat terhadap Akuntabilitas Pengelolaan APBD

Menurut Sulistoni (2003 dalam penelitian Sopanah dan Wahyudi 2010), pemerintah yang accountable memiliki ciriciri sebagai berikut: 1) mampu menyajikan informasi penyelenggaraan pemerintah secara terbuka, cepat dan tepat kepada masyarakat; 2) mampu memberikan pelayanan yang memuaskan bagi publik; 3) mampu memberikan ruang bagi masyarakat untuk terlibat dalam proses pembangunan dan pemerintahan; 4) mampu menjelaskan dan 
mempertanggungjawabkan setiap kebijakan publik secara proporsional; dan 5) adanya sarana bagi publik untuk menilai kinerja pemerintah. Melalui pertanggungjawaban publik, masyarakat dapat menilai derajat pencapaian pelaksanaan program dan kegiatan pemerintah.

Akuntabilitas publik akan tercapai jika pengawasan yang dilakukan oleh dewan dan masyarakat berjalan secara efektif. Hal ini juga di dukung oleh pendapatnya Rubin (1996) yang menyatakan bahwa untuk menciptakan akuntabilitas kepada publik diperlukan partisipasi pimpinan instansi dan warga masyarakat dalam penyusunan dan pengawasan keuangan daerah (APBD). Sehingga akuntabilitas publik yang tinggi akan dipengaruhi oleh fungsi pengawasan yang dilakukan oleh dewan, sehingga hipotesis utamanya dirumuskan sebagai berikut:

$\mathrm{H} 2$ :Sistem pengawasan melekat berpengaruh positif terhadap akuntabilitas pengelolaan APBD.

\section{Pengaruh Prinsip Transparansi terhadap Akuntabilitas Pengelolaan APBD}

Transparansi terkandung juga didalamnya secara tersirat bagaimana pemerintah daerah harus melaporkan rencana, pengelolaan dan juga laporan akhir yang berupa laporan keuangan anggaran-anggaran yang dibutuhkan dan juga digunakan oleh pemerintah daerah secara transparan sehingga masyarakat luas dapat ikut mengetahuinya. Hal ini diperkuat adanya pendapat Mardiasmo (2002) menyebutkan bahwa transparansi pengelolaan keuangan daerah pada akhirnya akan menciptakan horizontal accountability antara pemerintah daerah dengan masyarakatnya sehingga tercipta pemerintahan daerah yang bersih, efektif, efisien, akuntabel, dan responsive terhadap aspirasi dan kepentingan masyarakat.
Sehingga hipotesis utamanya dirumuskan sebagai berikut:

H3:Penerapan prinsip transparansi berpengaruh positif terhadap akuntabilitas pengelolaan APBD.

\section{METODE PENELITIAN / METHODS} Populasi dan Sampel Penelitian

Populasi adalah keseluruhan kelompok yang terdiri dari orang, peristiwa atau sesuatu yang ingin diteliti penulis. Populasi dalam penelitian ini adalah DPRD Kabupaten Rembang karena objek ini dapat mewakili dari seluruh keuangan di Kabupaten Rembang. Sampel adalah bagian dari populasi. Menurut Widjaja (2005) bahwa administrasi diacukan sebagai kegiatan yang bersifat tulis-menulis tentang segala sesuatu yang terjadi dalam organisasi atau usaha. Kegiatan-kegiatan administrasi meliputi mengetik, mengirim surat, mencatat keluar dan masuknya, penyimpanan arsip, pekerjaan secretariat lainnya (proses pelayanan), kegiatan perencanaan, pengorganisasian, penggerakan serta pengawasan. Maka dari itu, penelitian ini mengambil sampel bagian sekretariat DPRD kabupaten Rembang yang terdiri dari 60 pegawai sehingga data yang diperoleh lebih akurat atau tidak ada bias dalam mencapai hasil yang lebih besar. Dengan adanya 60 pegawai maka penulis menyebarkan kuesioner penelitian sebanyak 60 kuesioner. Namun yang kembali hanya 14 kuesioner.

\section{Teknik Pengumpulan Data}

Teknik pengumpulan data primer ini terdiri dari beberapa cara yaitu metode survei, metode purposive sampling dan kuesioner. Metode pengumpulan data yang ditempuh dalam penelitian ini adalah menggunakan metode survei, metode purposive sampling dan penyebaran kuesioner. Menurut Indriantoro dan Supomo (1999 dalam proposal Andriyani 2012), metode survei 
merupakan metode pengumpulan data primer yang menggunakan pertanyaan lisan dan tertulis. Metode ini memerlukan adanya kontak atau hubungan antara peneliti dengan responden penelitian untuk memperoleh data yang diperlukan.

Penyebaran kuesioner dilakukan untuk memperoleh data diri responden dan penilaian pengaruh penerapan sistem informasi keuangan daerah, sistem pengawasan melekat dan prinsip transparansi terhadap akuntabilitas pengelolaan APBD. Masing-masing variabel diukur dengan model Skala Likert yaitu mengukur sikap dengan menyatakan setuju atau tidaksetujuannya terhadap pernyataan yang diajukan dengan skor 1 (STS=Sangat Tidak Setuju), 2 (TS=Tidak Setuju), 3 (ATS=Agak Tidak Setuju), 4 (AS=Agak Setuju), 5 ( $S=$ Setuju) dan 6 (SS=Sangat Setuju).

\section{Analisis Data}

Peneliti lebih cenderung menggunakan SmartPLS ketimbang dengan SPSS karena menurut Ghozali (2011) dengan SmartPLS merupakan metode yang powerfull dalam tidak mengasumsikan data harus dengan pengukuran skala tertentu namun bisa dengan jumlah sampel yang relatif kecil. Selain itu, dapat memberikan definisi yang pasti dari komponen skor. Maka analisis data dilakukan dalam penilitian ini menggunakan alat statistik yaitu SmartPLS dengan melakukan uji regresi berganda (multiple regression), karena dimaksudkan untuk mengetahui pengaruh langsung antar konstruk berdasarkan hipotesis.

\section{Uji Statistik Deskriptif}

Menurut Grahita (2017) tujuan dilakukan uji statistik deskriptif adalah menguji dan menjelaskan karakteristik sampel yang diobservasi. Hasilnya berupa tabel mean, deviasi standar, maksimum dan minimum yang diikuti dengan penjelasan berupa narasi yang menjelaskan interpretasi isi tabel berupa nama variabel yang diobeservasi.

\section{Uji Asumsi Klasik}

Menurut Grahita (2017), uji asumsi klasik ada empat uji yang dilakukan. Uji tersebut adalah sebagai berikut

\section{Uji Normalitas Data}

Distribusi normal dalam bentuknya mengikuti fungsi Gauss dikatakan simetris apabila $68 \%$ nilai standardized residuals terletak antara -1 dan $+1 ; 98 \%$ nilai standardized residuals terletak antara -2 dan +2 dan 99\% nilai standardized residuals terletak antara -3 dan +3 .

\section{Uji Heteroskedastisitas}

Uji ini hanya menguji apakah dalam model regresi terjadi atau terdapat ketidaksamaan varian nilai residual dari pengamatan satu ke pengamatan yang lain tetap (homokedastisidas) dan apabila terjadi perbedaan varian (heteroskedastisitas). Model regresi yang baik tidak terjadi heteroskedastisitas (homokedastisitas).

\section{Uji Autokorelasi}

Uji ini digunakan untuk menguji model regresi terdapat korelasi kesalahan pada priode $\mathrm{t}$ dengan kesalahan pada periode sebelumnya dengan signifikansi 5\% (batas atas 1.681 dan kurang dari 4) dikatakan tidak terjadi korelasi.

\section{Uji Multikolinearitas}

Uji ini batas tolerance 0.100 jika nilai tolerance kurang dari 0.100 maka tidak terjadi multikolineritas, batas coefficient kurang dari 5 maka dapat disimpulkan model regresi ini baik karena tidak terjadi multikolineritas dan batas coefficient correlation memiliki batas 95\% jika kurang dari 95\% masih dapat dikatakan tidak terjadi multikolineritas. 


\section{Uji F}

Menurut Grahita (2017), Uji F dikatakan signifikan didalam regresi berganda jika hasil analisis menunjukkan nilai $\mathrm{p} \leq 0.05$ maka model persamaan regresi signifikan pada level alfa 5\% (dikatakan sudah tepat).

\section{Uji Koefisien Determinasi $\left(\mathbf{R}^{\mathbf{2}}\right)$}

Menurut Grahita (2017), uji $\mathrm{R}^{2}$ besaran proporsi variasi variabel independen yang mampu menjelaskan variasi variabel dependen. Jika hasil $\mathrm{R}^{2}$ diestimasikan sebesar 0.63 maka variasi variabel independen diformulasikan dalam model riset mampu menjelaskan variasi variabel dependen $63 \%$, namun jika hanya $37 \%$ dijelaskan variabel independen lain yang tidak dimasukan dalam model riset.

\section{Uji Signifikasi Variabel (Uji T)}

Menurut Grahita (2017) uji T merupakan uji yang dilakukan setelah uji $\mathrm{F}$ dinyatakan signifikan. Dengan demikian hasil yang signifikan dari uji $\mathrm{T}$ adalah $\mathrm{p} \leq 0.05$ maka pengaruh variabel independen terhadap variabel dependen signifikan secara statistif pada level alfa $5 \%$.

\section{HASIL PENELITIAN DAN DISKUSI / RESULTS AND DISCUSSION}

Statistik deskriptif dalam penelitian ini menggunakan software PLS versi 3.0. Statistik deskriptif digunakan untuk peringkasan data dan penyajian hasil peringkasan data tersebut. Berikut tabel kategori yang digunakan untuk menilai per variabel dalam penelitian ini.

Tabel 6.1 Kategori

\begin{tabular}{|c|c|}
\hline Interval & Kategori \\
\hline $1,00 \mathrm{~s} / \mathrm{d} 1,82$ & Sangat Buruk \\
\hline $1,83 \mathrm{~s} / \mathrm{d} 2,66$ & Buruk \\
\hline $2,67 \mathrm{~s} / \mathrm{d} \mathrm{3,49}$ & Kurang Baik \\
\hline $3,50 \mathrm{~s} / \mathrm{d} \mathrm{4,32}$ & Cukup Baik \\
\hline $4,33 \mathrm{~s} / \mathrm{d} \mathrm{5,16}$ & Baik \\
\hline $5,17 \mathrm{~s} / \mathrm{d} 6,00$ & Sangat Baik \\
\hline
\end{tabular}

Untuk mengukur gejala pusat dan variasi kelompok serta varians data dapat digunakan minimum, maksimum, mean, dan standar deviation. Hasil deskriptif variabel penelitian ini dapat ditunjukkan pada tabel berikut :

Tabel 6.2 Deskriptif Variabel Penelitian

\begin{tabular}{|c|c|c|c|c|c|}
\hline & $\mathrm{N}$ & $\begin{array}{l}\text { Minim } \\
\text { um }\end{array}$ & $\begin{array}{l}\text { Maxi } \\
\text { mum }\end{array}$ & Mean & $\begin{array}{c}\text { Std. } \\
\text { Deviation }\end{array}$ \\
\hline $\mathrm{X} 1.1$ & 14 & 2,00 & 6,00 & $\begin{array}{r}5,000 \\
0\end{array}$ & 96077, \\
\hline X1.2 & 14 & 1,00 & 6,00 & $\begin{array}{r}4,500 \\
0\end{array}$ & 1,28602 \\
\hline X1.3 & 14 & 2,00 & 6,00 & $\begin{array}{r}4,571 \\
4\end{array}$ & 1,01635 \\
\hline X1.4 & 14 & 2,00 & 6,00 & $\begin{array}{r}4,714 \\
3\end{array}$ & 99449, \\
\hline$\times 1.5$ & 14 & 2,00 & 6,00 & $\begin{array}{r}4,642 \\
9\end{array}$ & 1,00821 \\
\hline$\times 1.6$ & 14 & 2,00 & 6,00 & $\begin{array}{r}4,500 \\
0\end{array}$ & 1,09193 \\
\hline$\times 1.7$ & 14 & 2,00 & 6,00 & $\begin{array}{r}4,642 \\
9\end{array}$ & 1,00821 \\
\hline
\end{tabular}


Balance Vol. XVI No. 1 | Januari 2019

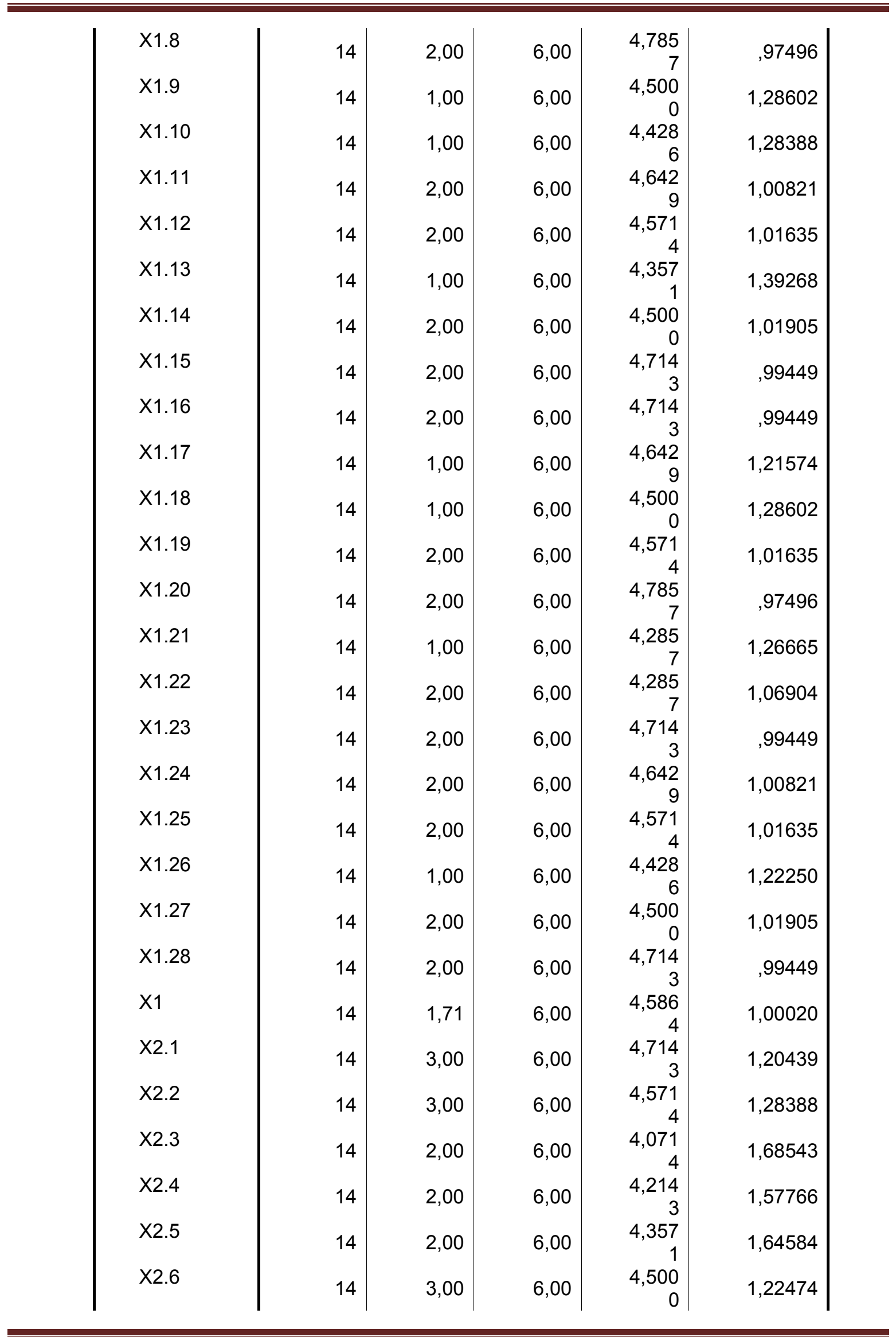


Balance Vol. XVI No. 1| Januari 2019

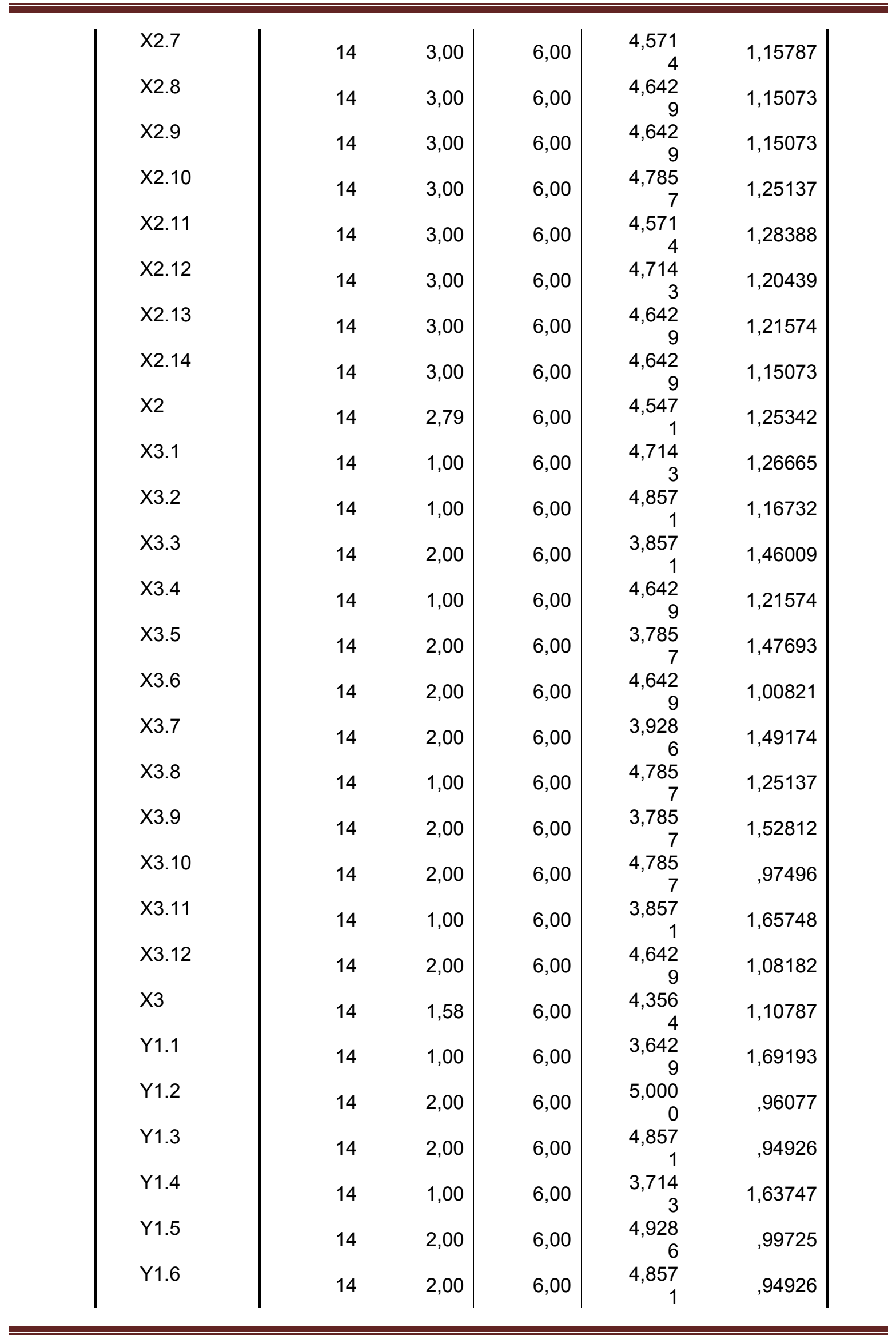


Balance Vol. XVI No. 1| Januari 2019

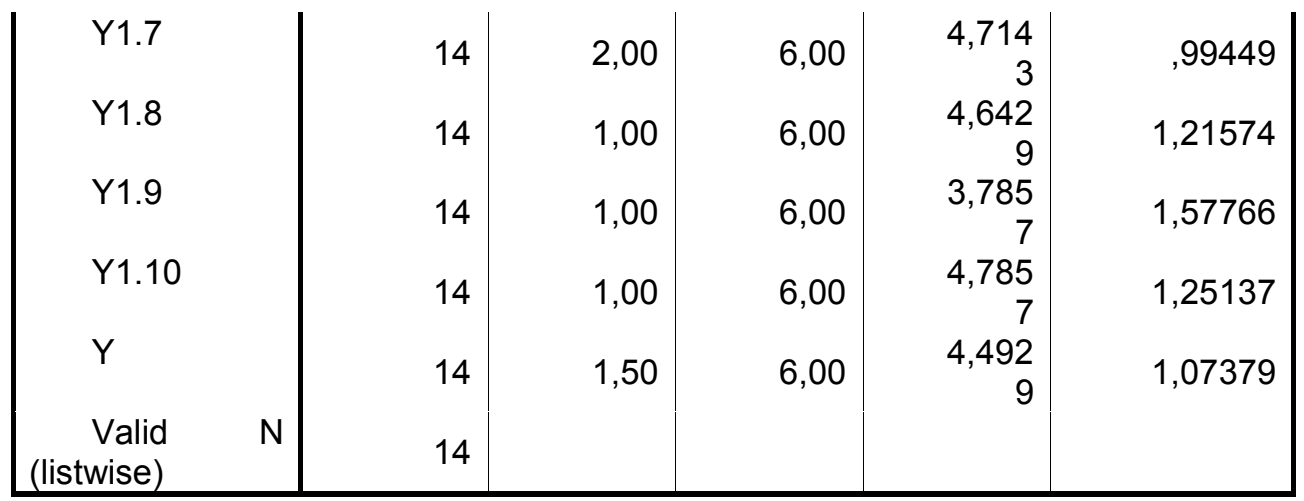

Hasil deskriptif pada sistem informasi keuangan daerah (X1) diperoleh nilai minimum 2,00, nilai maksimal 6,00; rata-rata sebesar 5,00 dan standar deviasi sebesar 1,39268. Jika dilihat nilai rata-rata diatas 3,5 (nilai tengah antara 1 dan 6), menunjukkan bahwa sistem informasi keuangan daerah di Kabupaten Rembang termasuk dalam kriteria yang baik, sehingga sistem informasi ini mampu memberikan informasi kepada seluruh manager keuangan yang berkaitan dengan aktivitas keuangan organisasi, yang dapat digunakan untuk peramalan tren perekonomian masa depan, mengelola aliran dana yang melalui organisasi dan mengendalikan keuangan pemerintah daerah.

Hasil deskriptif pada pengawasan melekat (X2) diperoleh nilai minimum 2,79, nilai maksimal 6.00 , rata-rata sebesar 4,8571 dan standar deviasi sebesar 1,28388. Jika dilihat nilai rata-rata diatas 3,5 (nilai tengan antara 1 dan 6), menunjukkan bahwa sistem pengawasan keuangan daerah termasuk dalam kriteria yang baik, sehingga usaha-usaha untuk mengawasi serta mengendalikan pegawai secara langsung yang dilakukan oleh setiap unsur pimpinan dalam suatu organisasi, dirasakan telah efektif dan mampu menjangkau semua lini dalam unit kerja yang ada.

Untuk variabel prinsip transparasi (X3) diperoleh nilai minimum 2,00 , nilai maksimal 6,00, rata-rata sebesar 4,8571 dan standar deviasi sebesar 1,65748. Jika dilihat nilai rata- rata diatas 3,5 (nilai tengah antara 1 dan 6), menunjukkan prinsip transparasi yang dilakukan pemerintah daerah Kabupaten Rembang dapat dikategorikan baik. Artinya informasi yang disampaikan anggota DPRD Kabupaten Rembang kepada publik telah transparan, mudah diakses, dan disampaikan tepat waktu. Dengan demikian masyarakat akan mengetahui informasi tentang kebijakan, proses pembuatan dan pelaksanaannya, serta hasil-hasil yang telah dicapai.

Hasil deskriptif pada akuntabilitas pengelolaan APBD (Y) diperoleh nilai minimum 2,00 nilai maksimal 6,00, rata-rata sebesar 4,4929 dan standar deviasi sebesar 1,07379, menunjukkan bahwa akuntansibilitas pengelolaan APBD di Kabupaten Rembang termasuk dalam kriteria yang baik. Artinya dalam penyusunan anggaran dan pengelolaan keuangan di DPRD Kabupaten Rembang mampu menyajikan informasi penyelenggaraan pemerintah secara terbuka, cepat, dan tepat kepada masyarakat; mampu memberikan pelayanan yang memuaskan bagi publik; mampu memberikan ruang bagi masyarakat untuk terlibat dalam proses pembangunan dan pemerintahan; mampu menjelaskan dan mempertanggungjawabkan setiap kebijakan publik secara proporsional; dan adanya sarana bagi publik untuk menilai kinerja pemerintah.

\section{Uji Normalitas Data}


Distribusi normal dalam bentuknya mengikuti fungsi Gauss dikatakan simetris apabila $68 \%$ nilai standardized residuals terletak antara -1 dan $+1 ; 98 \%$ nilai standardized residuals terletak antara -2 dan +2 dan 99\% nilai standardized residuals terletak antara -3 dan +3 . Berikut tabel uji normalitas data. Distribusi normal dalam bentuknya mengikuti fungsi Gauss dikatakan simetris apabila $68 \%$ nilai standardized residuals terletak antara -1 dan $+1 ; 98 \%$ nilai standardized residuals terletak antara -2 dan +2 dan 99\% nilai standardized residuals terletak antara -3 dan +3 . Berikut tabel uji normalitas data.

Tabel 6.3 Residuals Statistics

\begin{tabular}{|c|c|c|c|c|c|}
\hline & $\begin{array}{l}\text { Minim } \\
\text { um }\end{array}$ & $\begin{array}{l}\text { Maxim } \\
\text { um }\end{array}$ & Mean & $\begin{array}{c}\text { Std. } \\
\text { Deviation }\end{array}$ & $\mathrm{N}$ \\
\hline Predicted Value & 1.5000 & 6.0000 & 4.4929 & 1.07379 & 14 \\
\hline Residual & .00000 & .00000 & .00000 & .00000 & 14 \\
\hline Predicted & -2.787 & 1.404 & .000 & 1.000 & 14 \\
\hline Value & & & & & \\
\hline Std. Residual & .000 & .000 & .000 & .000 & 14 \\
\hline
\end{tabular}

a. Dependent Variable: $Y$

Hasil perhitungan diketahui bahwa nilai standar residual terletak antara nilai min 0.000 dan nilai maksimal 0.000 maka dapat dikatakan bahwa variabel $\mathrm{X} 1, \mathrm{X} 2$ dan X3 terhadap Y memiliki distribusi normal dalam bentuknya mengikuti fungsi Gauss dikatakan simetris apabila $68 \%$ nilai standardized residuals terletak antara -1 dan +1 .

\section{Uji Heteroskedastisitas}

Uji ini hanya menguji apakah dalam model regresi terjadi atau terdapat ketidaksamaan varian nilai residual dari pengamatan satu ke pengamatan yang lain tetap (homokedastisidas) dan apabila terjadi perbedaan varian (heteroskedastisitas). Model regresi yang baik tidak terjadi heteroskedastisitas (homokedastisitas). 
Tabel 6.4 ANOVA

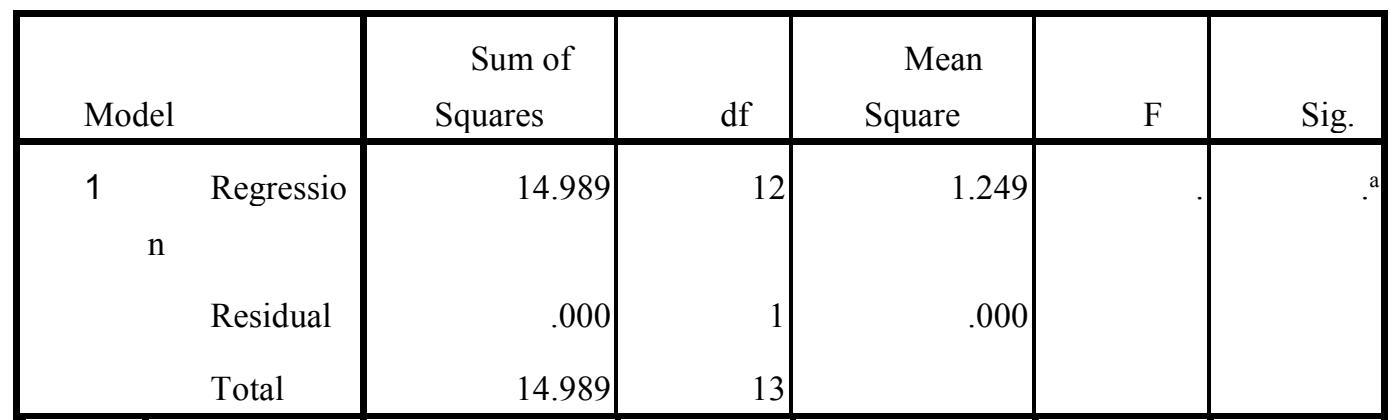

a. Predictors: (Constant), X3, X2.10, X1.28, X2.3, X3.8, X1.2, X1.3, X2.6, X1.23, X3.12,

\section{$\mathrm{X} 3.2, \mathrm{X} 1.13$}

b. Dependent Variable: Y

Hasil perhitungan nilai residual berada pada nilai 0.000 yang berarti bahwa model regresi terjadi atau terdapat ketidaksamaan varian nilai residual dari pengamatan satu ke pengamatan yang lain atau model regresi yang baik tidak terjadi heteroskedastisitas (homokedastisitas).

\section{Uji Autokorelasi}

Model regresi terdapat korelasi kesalahan pada priode $\mathrm{t}$ dengan kesalahan pada periode sebelumnya dengan signifikansi diatas 5\% (batas atas 1.681 dan kurang dari 4) dikatakan tidak terjadi korelasi.

Tabel 6.5 Autokorelasi

\begin{tabular}{|l|l|l|l|l|}
\hline & $\mathrm{X} 1$ & $\mathrm{X} 2$ & $\mathrm{X} 3$ & $\mathrm{Y}$ \\
\hline $\mathrm{X} 1$ & 1,000000 & & & \\
\hline $\mathrm{X} 2$ & 0,652027 & 1,000000 & & \\
\hline $\mathrm{X} 3$ & 0,934225 & 0,563379 & 1,000000 & \\
\hline $\mathrm{Y}$ & 0,969595 & 0,529147 & 0,962288 & 1,000000 \\
\hline
\end{tabular}

Variable SKID (X1), sistem pengawasan melekat (X2) dan prinsip transparansi (X3) memiliki tingkatan signifikansi yang tinggi karena memiliki significancy di atas 0.5 .

\section{Uji multikoloniaritas}

Hasil uji multikolineritas menunjukkan bahwa variabel X1, X2 dan X3 terhadap Y, memiliki bartas coefficient correlation memiliki batas 95\% jika kurang dari 95\% maka dapat disimpulkan model regresi ini baik karena tidak terjadi multikolineritas dan batas. Selain itu, batas tolerance 0.100 jika nilai tolerance kurang dari 0.100 dari setiap variabel baik X1, X2 dan X3 maka tidak 
terjadi multikolineritas. Hal ini terlihat pada tabel berikut.

\begin{tabular}{|c|c|c|c|c|c|c|c|c|c|c|c|}
\hline \multicolumn{12}{|c|}{ Coefficients $^{a}$} \\
\hline \multirow{2}{*}{\multicolumn{2}{|c|}{ Model }} & \multicolumn{2}{|c|}{ Unstandardized Coefficients } & \multirow{2}{*}{$\begin{array}{c}\text { Standardized } \\
\text { Coefficients } \\
\text { Beta }\end{array}$} & \multirow[b]{2}{*}{$t$} & \multirow[b]{2}{*}{ Sig. } & \multicolumn{3}{|c|}{ Correlations } & \multicolumn{2}{|c|}{ Collinearity Statistics } \\
\hline & & B & Std. Error & & & & Zero-order & Partial & Part & Tolerance & VIF \\
\hline \multirow[t]{13}{*}{1} & (Constant) & $4.049 \mathrm{E}-14$ & .000 & & .000 & 1.000 & & & & & \\
\hline & $\mathrm{x} 1.2$ & -.059 & .000 & -.071 & -961520.498 & .000 & .833 & -1.000 & -.007 & .009 & 116.246 \\
\hline & $\mathrm{X} 1.3$ & .110 & .000 & .104 & 3908001.251 & .000 & .878 & 1.000 & .027 & .066 & 15.083 \\
\hline & $\mathrm{x} 1.13$ & .114 & .000 & .148 & 1741909.826 & .000 & .809 & 1.000 & .012 & .006 & 155.000 \\
\hline & $X 1.23$ & -.105 & .000 & -.097 & -1848763.031 & .000 & .848 & -1.000 & -.013 & .017 & 58.897 \\
\hline & $\mathrm{X} 1.28$ & .333 & .000 & .309 & $1.063 \mathrm{E} 7$ & .000 & .891 & 1.000 & .073 & .055 & 18.066 \\
\hline & $\times 2.3$ & .028 & .000 & .044 & 2098712.856 & .000 & .502 & 1.000 & .014 & .107 & 9.317 \\
\hline & $\times 2.6$ & -.081 & .000 & -.093 & -3299643.496 & .000 & .488 & -1.000 & -.023 & .059 & 16.952 \\
\hline & $\times 2.10$ & .010 & .000 & .011 & 266487.238 & .000 & .457 & 1.000 & .002 & .027 & 37.426 \\
\hline & $\times 3.2$ & .463 & .000 & .504 & 8912772.736 & .000 & .920 & 1.000 & .061 & .015 & 68.442 \\
\hline & $\times 3.8$ & -.354 & .000 & -.413 & $-1.427 \mathrm{E} 7$ & .000 & .812 & -1.000 & -.098 & .056 & 17.933 \\
\hline & $\times 3.12$ & -.087 & .000 & -.088 & -1825684.643 & .000 & .865 & -1.000 & -.012 & .020 & 49.324 \\
\hline & $x 3$ & .629 & .000 & .649 & $1.579 \mathrm{E} 7$ & .000 & .958 & 1.000 & .108 & .028 & 36.104 \\
\hline
\end{tabular}

a. Dependent Variable: $Y$

\section{Uji F}

ANOVA

\begin{tabular}{|rl|r|r|r|r|r|}
\hline \multicolumn{1}{|c|}{} & \multicolumn{1}{c|}{$\begin{array}{c}\text { Sum of } \\
\text { Sodel }\end{array}$} & Squares & df & Mean Square & \multicolumn{1}{c|}{ F } & Sig. \\
\hline 1 & Regression & 14,575 & 3 & 4,858 & 117,247 &, $000^{a}$ \\
& Residual &, 414 & 10 &, 041 & & \\
& Total & 14,989 & 13 & & & \\
\hline
\end{tabular}

a. Predictors: (Constant), X3, X2, X1

b. Dependent Variable: $Y$

Uji $\mathbf{R}^{2}$

Untuk menilai pengaruh variabel laten independen terhadap variabel laten dependen apakah mempunyai pengaruh substantive. Berikut adalah tabel pengaruhnya:

Tabel 6.7 R Square

\begin{tabular}{|l|l|l|}
\hline & R Square & Cronbachs Alpha \\
\hline X1 & & 0,993372 \\
\hline X2 & & 0,994807 \\
\hline X3 & & 0,967516 \\
\hline Y & 0,977439 & 0,971326 \\
\hline
\end{tabular}

Dalam perhitungan $\mathrm{R}^{2}$ sebesar 0.977239 menjelaskan variasi variabel dependen $97 \%$, maka variasi variabel independen namun jika hanya 3\% dijelaskan variabel diformulasikan dalam model riset mampu 
independen lain yang tidak dimasukan dalam model riset.

\section{Uji Signifikasi Variabel (Uji T)}

Setelah mengetahui dan melakukan berbagai uji yang telah dipaparkan sebelumnya maka didapatkan hasil pengujian hipotesis. Berikut adalah hasil uji hipotesis.

Tabel 6.8 T-statistic

\begin{tabular}{|l|l|}
\hline & T Statistics $(\mid \mathrm{O} /$ STERR $\mid)$ \\
\hline $\mathrm{X} 1->\mathrm{Y}$ & 9,237760 \\
\hline $\mathrm{X} 2->\mathrm{Y}$ & 3,150699 \\
\hline $\mathrm{X} 3->\mathrm{Y}$ & 7,270543 \\
\hline
\end{tabular}

Hasil tersebut dapat dibaca dengan melakukan uji t statistik yaitu dengan membandingkan antara hasil $t$ hitung $(t$ statistik) dengan $t$ tabel. Dalam hal ini t tabel ditentukan signifikan pada 0,05 (t hitung/Tstatistics $>$ daripada $t$ tabel 1,96). Dengan adanya tabel 4.12 tersebut diatas, maka dapat disajikan seperti gambar 4.1 berikut ini

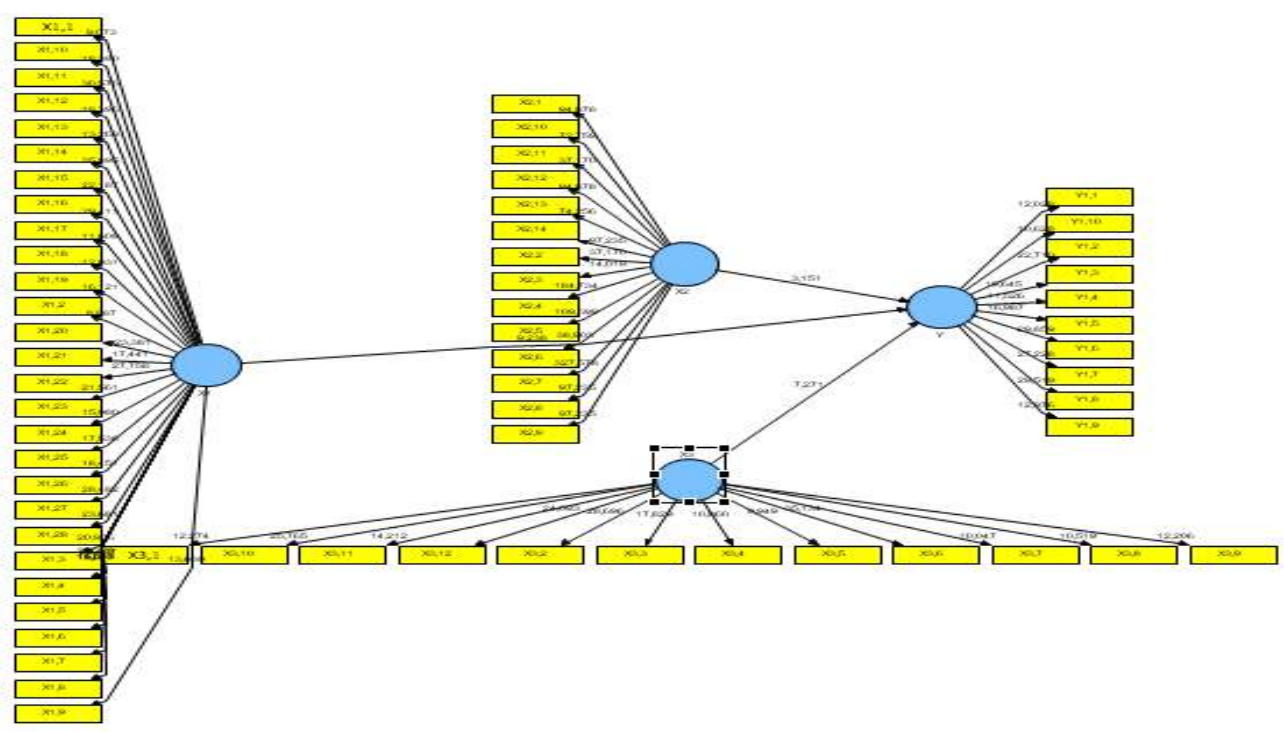

SIMPULAN, SARAN DAN KETERBATASAN PENELITIAN SIMPULAN

\section{Pengaruh Sistem Informasi Keuangan Daerah terhadap Akuntabilitas pengelolaan APBD}

Setelah melakukan pengujian terhadap data maka didapatkan hasil bahwa pengaruh sistem informasi keuangan daerah berpengaruh signifikan positif terhadap akuntabilitas pengelolaan APBD, terbukti dari hasil Inner Model mempunyai t statistik sebesar 9,237760. Jadi t statistik $>$ dari t tabel signifikan pada 0,05 ( $\mathrm{t}$ statistik $>\mathrm{t}$ tabel 1,96 ). Ini berarti bahwa Hipotesis1 $\left(\mathrm{H}_{1}\right)$ yang menyatakan bahwa "Penerapan sistem informasi keuangan daerah berpengaruh positif terhadap akuntabilitas pengelolaan $A P B D "$ 
Semakin baik penerapan sistem informasi keuangan daerah maka sistem ini akan memberikan manfaat yang lebih banyak seperti membantu pemerintah daerah dalam pengelolaan keuangan daerah yang mencakup perencanaan, pengelolaan dan pertanggungjawaban; menyusun laporan keuangan yang lebih efektif dan akurat; menyimpan data keuangan untuk keperluan manajemen lainnya; dan menyajikan informasi yang akurat, efektif dan efisien bagi pengguna laporan. Penerapan sistem informasi keuangan daerah yang akurat akan mempengaruhi informasi/pengelolaan keuangan yang akurat juga, sehingga hasilnya dapat dipertangungjawabkan. Dengan adanya hasil yang akurat dan dapat dipertanggungjawabkan maka "penerapan sistem informasi keuangan dapat berperan positif dalam mewujudkan akuntabilitas pengelolaan $A P B D$ ".

\section{Pengaruh Sistem Pengawasan Melakat Terhadap Akuntabilitas Pengelolaan APBD}

Setelah melakukan pengujian terhadap data maka didapatkan hasil bahwa pengaruh sistem pengawasan melekat terhadap akuntabilitas pengelolaan APBD mempunyai t statistik sebesar 3,150699. Jadi $\mathrm{t}$ statistik $>$ dari t tabel signifikan pada 0,05 (t statistik $>\mathrm{t}$ tabel 1,96), ini berarti bahwa Hipotesis2 $\left(\mathrm{H}_{2}\right)$ yang menyatakan bahwa "Sistem pengawasan melekat berpengaruh positif terhadap akuntabilitas pengelolaan APBD."

Menurut Rubin (1996) yang menyatakan bahwa untuk menciptakan akuntabilitas kepada publik diperlukan partisipasi pimpinan instansi dan warga masyarakat dalam penyusunan dan pengawasan keuangan daerah (APBD). Sehingga akuntabilitas publik yang tinggi akan dipengaruhi oleh fungsi pengawasan yang dilakukan oleh dewan. Oleh karena itu, pemerintah dikatakan memiliki akuntabilitas pengelolaan keuangan yang baik jika pemerintah tersebut mampu menyajikan informasi penyelenggaraan pemerintah secara terbuka, cepat dan tepat kepada masyarakat; mampu memberikan pelayanan yang memuaskan bagi publik; mampu memberikan ruang bagi masyarakat untuk terlibat dalam proses pembangunan dan pemerintahan; mampu menjelaskan dan mempertanggungjawabkan setiap kebijakan publik secara proporsional; dan adanya sarana bagi publik untuk menilai kinerja pemerintah. Melalui pertanggungjawaban publik, masyarakat dapat menilai derajat pencapaian pelaksanaan program dan kegiatan pemerintah. Akuntabilitas publik akan tercapai jika pengawasan yang dilakukan oleh dewan dan masyarakat berjalan secara efektif.

\section{Pengaruh Prinsip Transparansi terhadap Akuntabilitas Pengelolaan APBD}

Setelah melakukan pengujian terhadap data maka didapatkan hasil bahwa pengaruh prinsip transparansi terhadap akuntabilitas pengelolaan APBD mempunyai t statistik sebesar 7,270543. Jadi t statistik $>$ dari $\mathrm{t}$ tabel signifikan pada 0,05 ( $\mathrm{t}$ statistik $>\mathrm{t}$ tabel 1,96), ini berarti bahwa Hipotesis $3\left(\mathrm{H}_{3}\right)$ yang menyatakan bahwa "Penerapan prinsip transparansi berpengaruh positif terhadap akuntabilitas pengelolaan APBD".

Menurut Mardiasmo menyebutkan bahwa transparansi pengelolaan keuangan daerah pada akhirnya akan menciptakan horizontal accountability antara pemerintah daerah dengan masyarakatnya sehingga tercipta pemerintahan daerah yang bersih, efektif, efisien, akuntabel, dan responsive terhadap aspirasi dan kepentingan masyarakat. Oleh karena itu, penerapan prinsip transparansi di dalam perencanaan, pelaksanaan, dan pelaporan pelaksanaan kegiatan memberikan keleluasan kepada masyarakat dan pihak-pihak yang 
berkepentingan dalam mendapatkan akses informasi yang diperlukan dengan berbagai media yang dimungkinkan. Dengan demikian penerapan prinsip transparansi terhadap pengelolaan keuangan akan mendorong terciptanya keterbukaan publik atas pengelolan keuangan. Mengingat keterbukaan publik atau kemudahan masyarakat dalam mendapatkan informasi yang diperlukan menjadi bagian penting dari akuntabilitas, maka penerapan prinsip transparansi terhadap pengelolaan keuangan akan mendorong terciptanya akuntabilitas pengelolaan APBD. Dengan kata lain penerapan prinsip transparansi atas pengelolaan keuangan berpengaruh positif terhadap akuntabilitas pengelolan APBD.

\section{SARAN}

1. Bagi sekretariat DPRD kabupaten Rembang, hendaknya dalam meningkatkan kinerja sistem informasi keuangan daerah, yang relevan, akurat dan dapat dipertanggungjawabkan. Selain itu fungsi pengawasan pada anggota Dewan hendaknya dapat berjalan dengan baik sehingga proses atau usaha-usaha untuk mengawasi serta mengendalikan pegawai secara langsung yang dilakukan oleh setiap unsur pimpinan dalam suatu organisasi, sehingga dirasakan lebih efektif untuk mampu menjangkau semua lini dalam unit kerja yang ada. Selain itu proses penyusunan APBD ini hendaknya lebih transparan kepada publik dengan menyediakan berbagai akses informasi yang mudah.

2. Penelitian ini mengambil obyek yang terbatas yakni pada Sekretariat DPRD Kabupaten Rembang. Pada peneliti berikutnya perlu dilakukan pengamatan dengan obyek yang lebih luas, sehingga lebih dapat dijadikan acuan bagi kepentingan generalisasi permasalahan.

\section{DAFTAR PUSTAKA / BIBLIOGRAPHY}

Andriyani, Nurulita. 2012. Pengaruh Kecerdasan Emosional dan Kecerdasan Intelekrual terhadap Tingkat Pemahaman Akuntansi. Proposal-S1. Fakultas Ekonomi. Universitas Islam Indonesia. Yogyakarta.

Anthony, Robert N and Govindarajan, Vijay. 2011. Sistem Pengendalian Manajemen. Edisi 12. Karisma Publishing Group. Tangerang.

Atarwaman, Rita J. D. 2008. Pengaruh Struktur Kewenangan, Karakteristik Sistem Informasi Keuangan Daerah dan Perilaku Manajer terhadap Cost Consciousness. Tesis S-2. Universitas Diponegoro. Semarang.

Bastian, Indra. 2001. Manual Akuntansi Keuangan Pemerintah Daerah. Edisi Pertama. BPFE. Yogyakarta.

Cooper, Donald R dan Schinder, Pamela S. 2006. Metode Riset Bisni, Edisi Sembilan. PT Media Global Edukasi. Jakarta.

Departemen Keuangan RI. 2006. Kumpulan Peraturan Pemerintah Pelaksana UU Nomor 33 Tahun 2004. Cetakan I. Pusat Pengkajian Ekonomi dan Keuangan Daerah.

Deutari, Cindy. 2012. Pengaruh Pengawasan Melekat dan Fungsi Anggaran terhadap Tata Kelola yang Baik (Good Governance) di Pemerintah Kota Tasikmalay. skripsi S-1. Universitas Siliwangi. Tasikmalaya.

Forum Dosen Akuntansi Sektor Publik. 2006. Standar Akuntansi Pemerintahan Telaah Kritis PP Nomor 24 Tahun 2005. Edisi Pertama. BPFE. Yogyakarta.

Ghozali, Imam. 2011. Aplikasi Analisis Multivariate dengan Program IBM SPSS. Edisi 5. Semarang: Universitas Diponegoro.

Ghozali, Imam. 2011. Structural Equaling Modeling Metode Alternatif dengan Partial Least Square (PLS). Edisi 3. Badan Penerbit Universitas Diponegoro. Semarang.

Grahita. 2017. Metode Riset Akuntansi Pendekatan Kuantitatif. Salemba Empat. Jakarta.

Krina, Loina Lalolo. 2003. Indikator dan Alat Ukur Prinsip Akuntabilitas, Transparansi dan Partisipasi. Skretariat Good Public Governance Badan Perencanaan Pembangunan Nasional. Jakarta.

Krismiaji. 2005. Sistem Informasi Akuntansi. Edisi kedua. Unit Penerbit dan Percetakan 
Balance Vol. XVI No. 1| Januari 2019

Akademik Manajemen Perusahaan YKPN. Yogyakarta.

Lembaga Administrasi Negara Republik Indonesia. 2003. Sistem Administrasi Negara Kesatuan Republik Indonesia (SANKRI). Cetakan Pertama. Perum Percetakan Negara RI. Jakarta.

Malichah, Hikmah Nurul. 2010. Pengaruh Kejelasan dan Sasaran Anggaran, Pengendalian Akuntansi dan Sistem Pelaporan terhadap Akuntabilitas Kinerja Instansi Pemerintah Daerah Yogyakarta. Skripsi S-1. Fakultas Ekonomi. Universitas Ahmad Dahlan. Yogyakarta.

Mardiasmo. 2002. Otonomi dan Manajemen Keuangan Daerah. Andi. Yogyakarta.

Mardiyanto, Handono. 2009. Inti sari manajemen keuangan. Jakarta. Grasindo.

Martani, Dwi dan Zaelani, Fazri. 2011. Pengaruh Ukuran, Pertumbuhan, dan Kompleksitas terhadap Pengendalian Intern Pemerintah Daerah. Skripsi S-1. Universitas Syiah Kuala Banda Aceh. Aceh.

Morissan. 2012. Metode Penelitian Survei. Cetakan Ke-1. Kencana Prenada Media Group. Jakarta.

Rahmanurrasjid, Amin. 2008. Akuntabilitas dan Transparansi dalam Pertanggungjawaban Pemerintah Daerah untuk Mewujudkan Pemerintah yang Baik Di Daerah. Tesis S-2. Universitas Diponegoro. Semarang.

Santoso, Pandji. 2008. Administrasi Publik Teori dan Aplikasi Good Governanc. Cetakan Pertama. PT Refika Aditama. Bandung.

Solikhah, Bangdiyatus, Rohman, dan Meiranto. 2010. Implikasi Intellectual Capital terhadap Financial Performance, Growth dan Market Value; Studi Empiris dengan Pendekatan Simplitic Specification. Tesis S-2. Universitas Jenderal Soedirman. Purwokerto.

Sopanah dan Wahyudi, Isa. 2010. Pengaruh Akuntabilitas Publik, Partisipasi
Masyarakat dan Transparansi Kebijakan Publik Terhadap Hubungan Antara Pengetahuan Anggaran Dengan Pengawasan Keuangan Daerah (APBD). Skripsi S-1. Universitas Widya Gama Malang. Malang.

Suhanda Wati, Sinta. 2007. Analisis atas Pengawasan Fungsional Pengaruhnya terhadap Efektivitas Pengelolaan Keuangan Daerah pada Inspektorat Kota Bandung. Skripsi S-1. Universitas Komputer Indonesia. Jakarta.

Sulistoni. 2003. Fiqh Korupsi: Amanah Vs Kekuasaan. Somasi. Nusa Tenggara Barat.

Ulum MD, Ihyaul. 2009. Audit Sektor Publik Suatu Pengantar. Cetakan Pertama. PT Bumi Aksara. Jakarta.

Ulum, Ihyaul, Imam Ghozali dan Anis Chariri. 2010. Intellectual Capital dan Kinerja Keuangan Perusahaan; Suatu Analisis Pendekatan Partial Least Squar. Paper. Universitas Diponegoro. Semarang,

Widayaningsih, Aristanti, Triantoro, Alvian, dan Wiyantoro, Lili Sugeng. 2011. Hubungan Efektifitas Sistem Akuntansi Keuangan Daerah dan Pengendalian Intern Dengan Kualitas Akuntabilitas Keuangan: Kualitas Informasi Laporan Keuangan sebagai Variabel Intervening. Skripsi S1. Universitas Syiah Kuala Banda Aceh. Aceh.

Widjaja, H.A.W. 2007. Penyelenggaraan Otonomi di Indonesia dalam Rangka Sosialisasi UU Nomor 32 Tahun 2004 tentang Pemerintah Daerah. Edisi 1. PT Raja Grafido Persada. Jakarta. 